\title{
Effects of climate change and population growth on the transboundary Santa Cruz aquifer
}

\author{
Christopher A. Scott ${ }^{1,2, *}$, Sharon Megdal ${ }^{3}$, Lucas Antonio Oroz ${ }^{4}$, James Callegary ${ }^{5}$, \\ Prescott Vandervoet ${ }^{1}$
}

\author{
${ }^{1}$ Udall Center for Studies in Public Policy, ${ }^{2}$ School of Geography \& Development, and ${ }^{3}$ Water Resources Research Center, \\ University of Arizona, Tucson, Arizona 85721, USA \\ ${ }^{4}$ Comisión Nacional del Agua, Hermosillo, Sonora 83280, Mexico \\ ${ }^{5}$ Arizona Water Science Center, US Geological Survey, Tucson, Arizona 85719, USA
}

\begin{abstract}
The USA and Mexico have initiated comprehensive assessment of 4 of the 18 aquifers underlying their $3000 \mathrm{~km}$ border. Binational management of groundwater is not currently proposed. University and agency researchers plus USA and Mexican federal, state, and local agency staff have collaboratively identified key challenges facing the Santa Cruz River Valley Aquifer located between the states of Arizona and Sonora. The aquifer is subject to recharge variability, which is compounded by climate change, and is experiencing growing urban demand for groundwater. In this paper, we briefly review past, current, and projected pressures on Santa Cruz groundwater. We undertake first-order approximation of the relative magnitude of climate change and human demand drivers on the Santa Cruz water balance. Global circulation model output for emissions scenarios A1B, B1, and A2 present mixed trends, with annual precipitation projected to vary by $\pm 20 \%$ over the 21 st century. Results of our analysis indicate that urban water use will experience greater percentage change than climate-induced recharge (which remains the largest single component of the water balance). In the Mexican portion of the Santa Cruz, up to half of future total water demand will need to be met from non-aquifer sources. In the absence of water importation and with agricultural water use and rights increasingly appropriated for urban demand, wastewater is increasingly seen as a resource to meet urban demand. We consider decision making on both sides of the border and conclude by identifying short- and longer-term opportunities for further binational collaboration on transboundary aquifer assessment.
\end{abstract}

KEY WORDS: Climate change - Groundwater - Transboundary aquifers · Population growth

\section{INTRODUCTION}

The objective of this study is to analyze potential implications of climate change and human demand for water on the groundwater balance of the Santa Cruz Valley Aquifer in the USA-Mexico border region. The Southwest USA and adjoining Northwest Mexico, which already experience water scarcity, are expected to become drier over the 21st century (Karl et al. 2009). The variability of precipitation has led Diffenbaugh et al. (2008) to identify this region as a 'climate change hotspot'. Groundwater aquifers, as a result of the projected declines and greater variability of surface water, are expected to experience increased pumping to meet human demands for water. In this paper, we pay special attention to the Santa Cruz Valley Aquifer, one of 4 aquifers currently being assessed as part of the USA-Mexico Transboundary Aquifer Assessment Program (TAAP). The Santa Cruz Aquifer is subject to climate impacts on future water supply and variability, including flooding and drought. Evolving institutional arrangements 
to address these challenges are asymmetrical on opposite sides of the border, as detailed below. Fig. 1 shows the location of the Santa Cruz aquifer, shared between the states of Arizona and Sonora.

Historical antecedents demonstrate that water resources have always been crucial to human settlement and economic development in the Santa Cruz valley. During the Holocene, native peoples related to the present day Tohono O'odham inhabited riverine environments in the study area. Irrigation was practiced, but few remnants exist of large-scale irrigation works such as those employed by the Hohokam along the lower Santa Cruz, Gila, and Salt Rivers to the north. Europeans first made forays into the region in the mid-16th century, and established numerous settlements along the river. With Mexican independence from Spain in 1810, the region came under Mexican jurisdiction. Before the USA acquired the area north of the current border through the 1854 Gadsden Purchase (Tratado de la
Mesilla), the Santa Cruz River occupied a more central location in the Mexican state of Sonora. This socio-political shift brought with it new technologies, some of which allowed for increased exploitation of groundwater. The middle and upper Santa Cruz River basin experienced increasing use of groundwater, mostly due to agricultural and urban expansion in Tucson and Ambos Nogales (i.e. the town of Nogales on both sides of the border). Groundwater increasingly became the principal source of water to supply Tucson, Nogales, Arizona, and Nogales, Sonora (Logan 2002).

During the early 20th century, Mexico and the USA negotiated a series of agreements related to the border. Transboundary water resources were the subject of the 1944 treaty titled 'Utilization of Waters of the Colorado and Tijuana Rivers and of the Rio Grande,' which renamed the International Boundary Commission, created in 1889, as the International Boundary and Water Commission

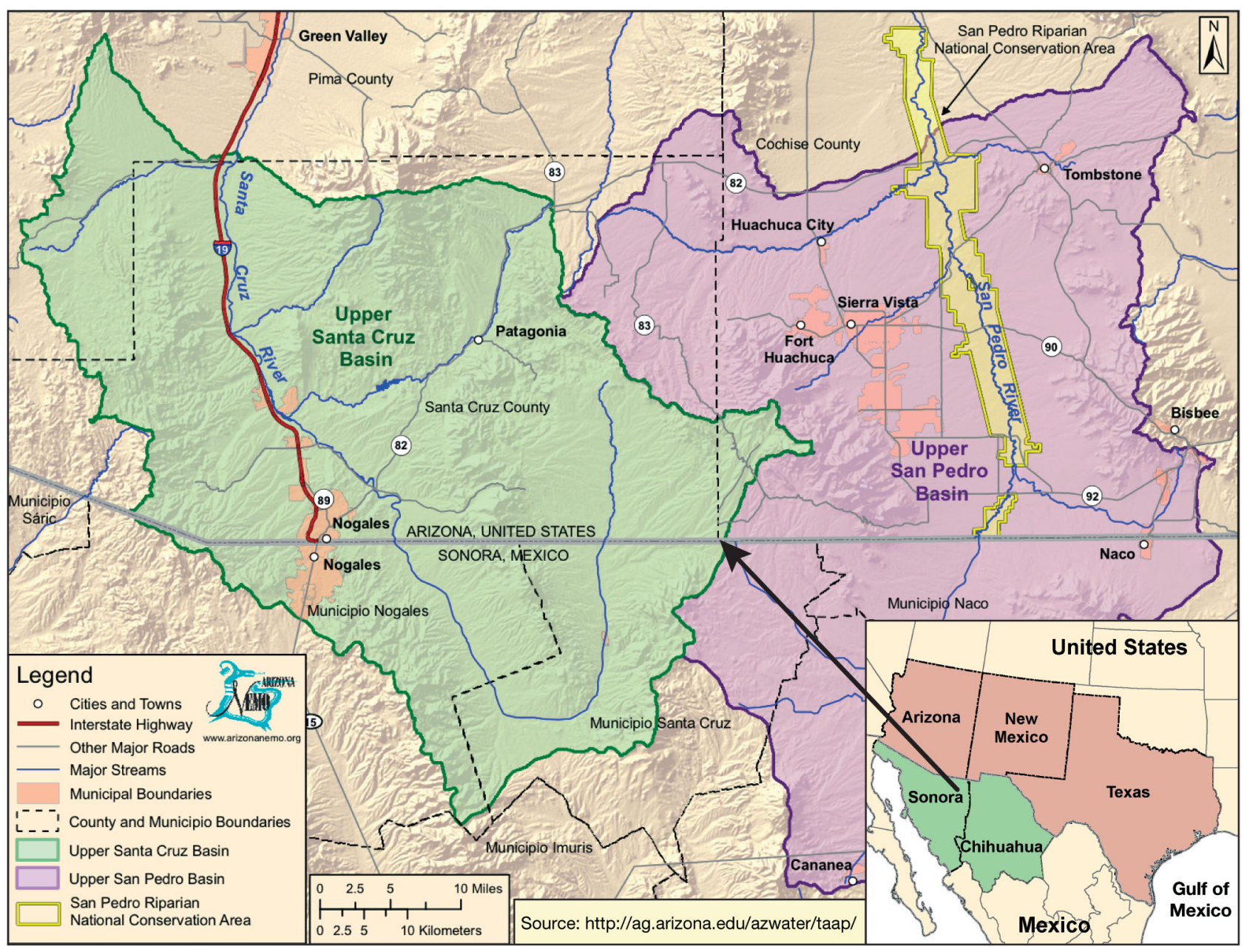

Fig. 1. Location of Arizona (USA)-Sonora (Mexico) transboundary aquifers 
(IBWC $;$ in Spanish, the Comision Internacional de Límites y Aguas, CILA), which is composed of both USA and Mexican Sections. The treaty emphasized shared surface waters and left groundwater essentially unaddressed. Subsequently, both sections of the IBWC passed a resolution (Minute 242) in 1973 in an effort to resolve transboundary groundwater issues. However, although Minute 242 establishes binational data sharing for groundwater data, it does not carry the same weight as the 1944 treaty (Mumme 2000), which results in binational groundwater issues being addressed on a case-by-case basis. While agreements such as Minute 227 and 276 specifically addressed sanitation and wastewater treatment issues for the Nogales Wash drainage and Ambos Nogales area, no Minute has specifically addressed the main stem of the Santa Cruz River. Studies that address individual shared aquifers were developed in response to local needs. In particular, the Mesilla and Hueco Bolson aquifers underlying El Paso, Texas, and adjoining southeastern New Mexico with Ciudad Juárez, Chihuahua in Mexico have received considerable attention, particularly relating to water quality and quantity challenges in this region of rapid growth and scarce water. Both Mesilla and Hueco Bolson aquifers are included in the TAAP.

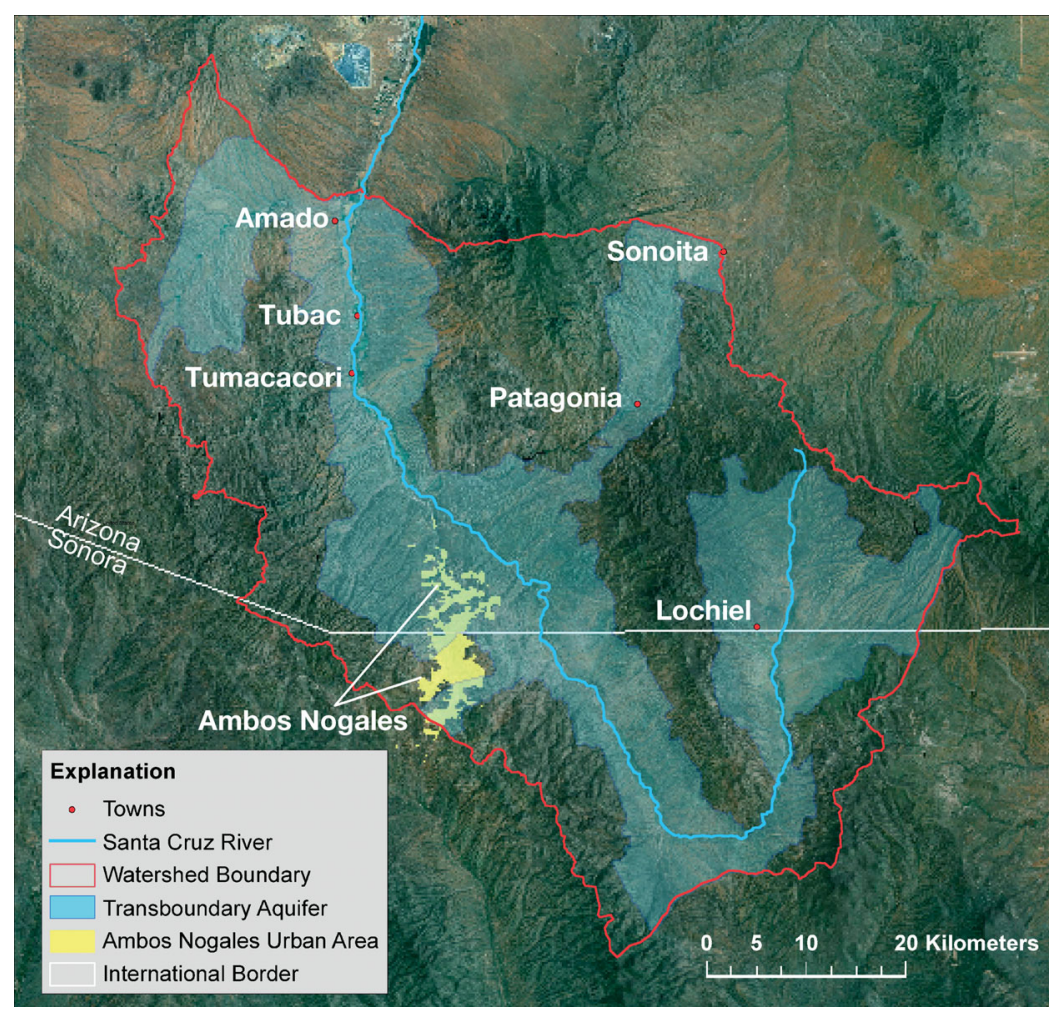

Fig. 2. Likely extent of Santa Cruz aquifer
Following this introduction and brief review of historical water use in the Santa Cruz River Valley, we present data and methods for our assessment of current and future demand for water resulting from projected population growth. We apply climate model simulations for precipitation under multiple emissions scenarios to the water balance and examine the implications for future water demands. Following this, we compare water management regimes on both sides of the border and review instances of effective cooperation as well as challenges. This section also presents salient information on the TAAP. The concluding section addresses future binational aquifer assessment priorities in light of the findings of this paper.

\section{DATA AND METHODS}

The Santa Cruz River originates in the San Rafael Valley of southeastern Arizona, flows south into Mexico, and then turns to the north, entering Arizona about $10 \mathrm{~km}$ east of the urban area of Ambos Nogales. The Nogales and Tucson portions of the Santa Cruz River basin have a combined drainage area of approximately $11780 \mathrm{~km}^{2}$ (Cevera Gomez 1997, Erwin 2007, ADWR 2008), as delimited by the Santa Cruz (1940 $\left.\mathrm{km}^{2}\right)$ and Tucson $\left(9840 \mathrm{~km}^{2}\right)$ Active Management Areas (AMAs). AMAs are the principal water management units used in Arizona, defined by the 1980 Groundwater Management Act. The Santa Cruz River and the San Pedro River to its east (which originates in Mexico) are both tributaries of the Gila River, which drains much of southern Arizona and parts of western New Mexico, and in turn is a tributary of the Colorado River. The Colorado River Basin covers $647000 \mathrm{~km}^{2}$ and flows through 7 USA and 2 Mexican states before flowing into the Sea of Cortez.

Fig. 2 shows the Santa Cruz aquifer delineated by Quaternary and Tertiary alluvial and sedimentary rock units on both sides of the border (Castro-Escárrega et al. 2000, Richard et al. 2000, Drewes et al. 2002). On the USA side of the border, the 3 main sedimentary/alluvial units are the Nogales Formation, the Older 
Alluvium, and the Younger Alluvium (Erwin 2007, Nelson 2007). These units are also found in the Mexican portion of the aquifer as well as in the USA in the San Rafael Valley, which is located in the uppermost portion of the basin. Most wells are located in the Younger Alluvium, as hydraulic conductivities are typically greater than $30 \mathrm{~m} \mathrm{~d}^{-1}$ (Towne \& Stephenson 2003, Tapia-Padilla 2005). However, storage in Younger Alluvium aquifers tends to be extremely limited, to the degree that the City of Nogales, Arizona regularly varies pumping rates from well to well in order to maintain adequate water levels. Hydraulic conductivities of the Older Alluvium tend to decrease from north to south and range from 1 to $10 \mathrm{~m} \mathrm{~d}^{-1}$ and that of the Nogales Formation is typically less than $0.3 \mathrm{~m} \mathrm{~d}^{-1}$ except in fractured zones where it may be higher. The thickness of the Nogales Formation in some areas exceeds $1000 \mathrm{~m}$. Thickness of the Older Alluvium
Outflow: $20 \%$

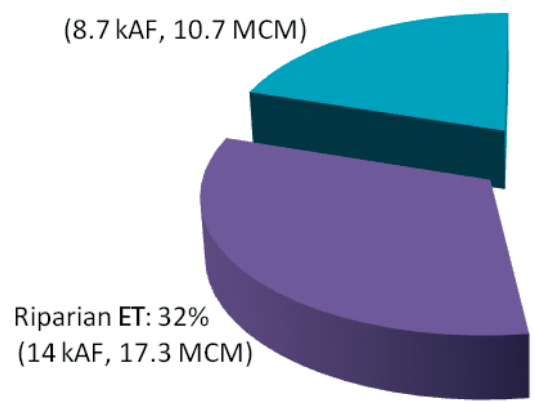

Fig. 3. USA Santa Cruz water use, 2006. kAF: 1000 acre feet; MCM: million cubic meters; ET: evapotranspiration. Source: www.azwater.gov/DWR/ WaterManagement/Content/AMAs/Assessment/Assessment4.htm
Municipal Use: $19 \%$ (8.3 kAF, 10.2 MCM)

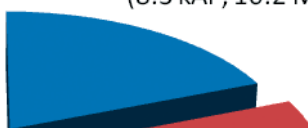

Industrial: $4 \%$ (1.8 kAF, 2.2 MCM)

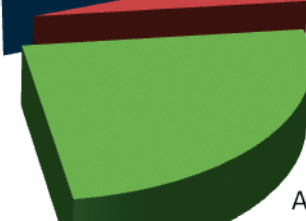

Agricultural: $25 \%$

(10.7 kAF, 13.2 MCM) ranges from a few meters to greater than $300 \mathrm{~m}$ while that of the Younger Alluvium is typically less than $50 \mathrm{~m}$ with widths highly variable and ranging from less than $100 \mathrm{~m}$ to about $5000 \mathrm{~m}$.

Key elements of the water budget, in millions of cubic meters (MCM) and thousands of acre-feet $(\mathrm{kAF})$, in the USA portion of the Santa Cruz basin are shown in Fig. 3. Evapotranspiration (ET) from natural vegetation is the largest component, with groundwater extraction for human uses split 51 and $49 \%$, respectively, between agriculture and municipal/ industrial uses. Water availability linked to climatic factors is highly variable (Figs. 4 \& 5). This variability, coupled with the locally limited extent and high permeability of the aquifer, result in significant intraand inter-annual fluctuation in water levels (Shamir et al. 2007), raising the need for careful management, not just of the aggregate water budget, but more importantly, of the spatial and temporal distribution of pumping and recharge.

The water budget in the Sonoran portion of the Santa Cruz does not account for riparian ET, a deficiency that the planned assessment process aims to address. The human use components are presented in Fig. 6. Note particularly the preponderance of urban/industrial use compared to agriculture, indicating the relatively limited ability to meet future demand for urban growth through reallocation. As we discuss below, transboundary wastewater flows represent a resource that Sonora will need to address directly. These flows are not accounted for in the outflow component in Fig. 6 but are conveyed to Arizona through a sewer line to the Nogales International Wastewater Treatment Plant (NIWTP; see further details below).

Table 1 synthesizes current estimates of the water balances for the USA (Santa Cruz AMA) and Mexican portions of the Santa Cruz aquifer. Both demonstrate positive balances, i.e. withdrawals are currently lower than recharge.

Based on these data, we consider climate and human-demand impacts on projected future water budgets. Methods are described in each subsection below.
Fig. 4. US Santa Cruz water availability, 2006. kAF: 1000 acre feet; MCM million cubic meters. Source: www.azwater.gov/Azdwr/WaterManagement/

Assessmenta/
Major Tributary Recharge 51\%

Mountain and Minor Tributary Recharge 15\%
(11.4 kAF, 14.1 MCM)

Recharge 20\%

(15.5 kAF, 19.1

MCM)

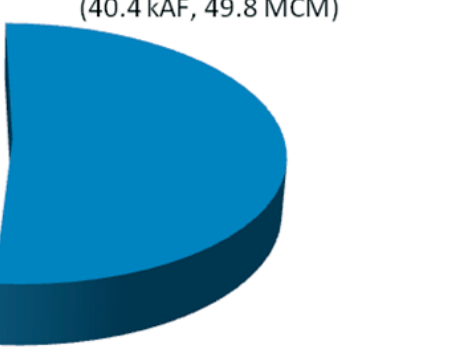




\section{Low range / Poor year (10th percentile)}

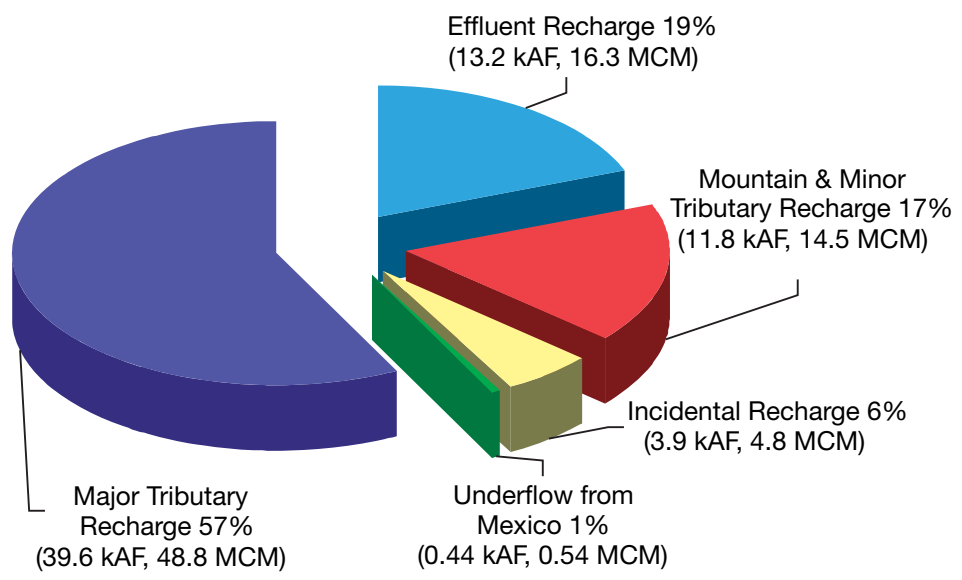

High range / Good year (90th percentile)

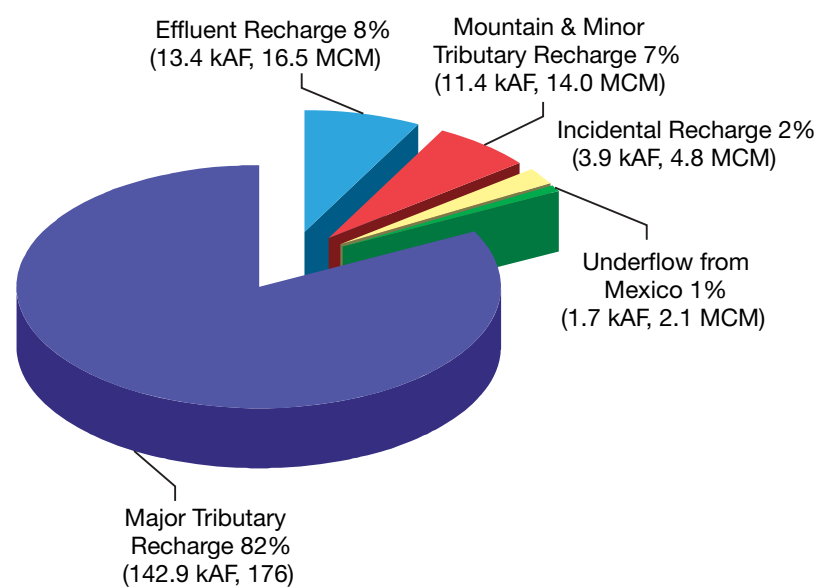

Fig. 5. Variability in USA Santa Cruz water availability. kAF: 1000 acre feet; MCM: million cubic meters

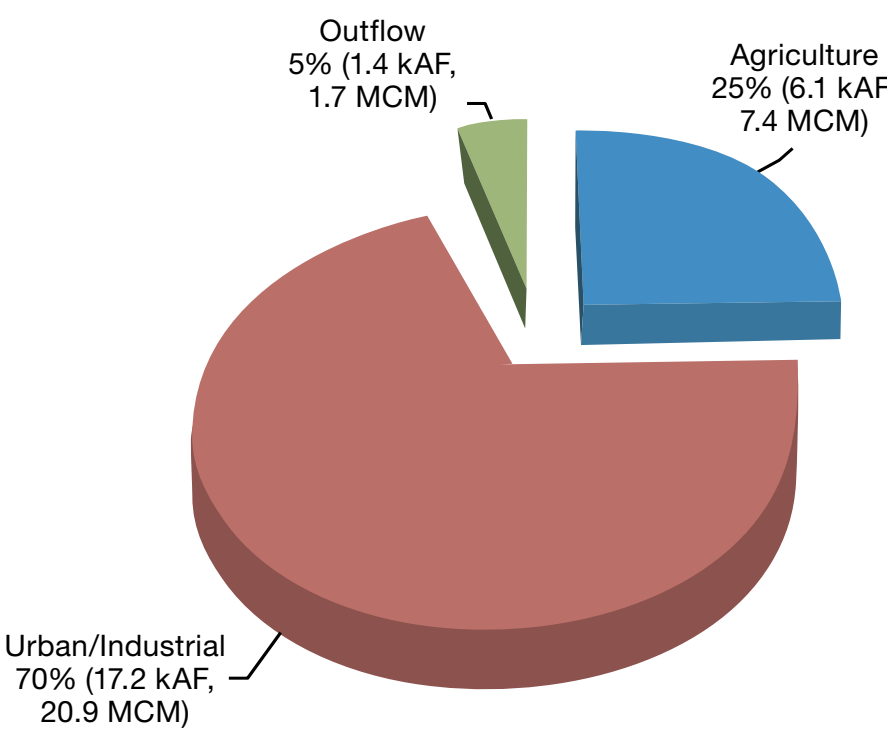

Fig. 6. Mexican Santa Cruz water use. kAF: 1000 acre feet; MCM: million cubic meters

Table 1. Santa Cruz aquifer estimated water balances for USA and Mexican portions. kAF: 1000 acre feet; MCM: million cubic meters; ET: evapotranspiration; $(-)$ : no data

\begin{tabular}{|c|c|c|c|c|}
\hline \multirow[b]{2}{*}{ Recharge } & \multicolumn{2}{|c|}{$\begin{array}{l}\overline{\text { USA }} \\
\left(\mathrm{MCM} \mathrm{yr}^{-1}\right)\left(\mathrm{kAF} \mathrm{yr}^{-1}\right)\end{array}$} & \multicolumn{2}{|c|}{ 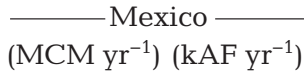 } \\
\hline & 86.1 & 69.8 & 30.0 & 24.3 \\
\hline Agricultural withdrawals & 13.2 & 10.7 & 7.4 & 6.0 \\
\hline Urban/industrial withdrawals & 12.8 & 10.45 & 20.9 & 16.9 \\
\hline Riparian ET & 17.3 & 14.0 & - & - \\
\hline Balance & 42.8 & 34.7 & 1.7 & 1.4 \\
\hline
\end{tabular}

\subsection{Climate change and variability}

Climate change can have marked impacts on groundwater (Loaiciga 2003, Earman \& Dettinger 2011). In this region, variable aquifer recharge represents a major source of water supply risk for dependent populations on both sides of the border. The criteria we applied in reviewing multiple global climate models were guided by consideration of model skill in simulating dominant regional climate (Brekke et al. 2008). For the region comprising the Santa Cruz binational aquifer, the North American Monsoon (NAM) is the major source of annual precipitation (Lin et al. 2008), which averages $407 \mathrm{~mm}$ annually in Ambos Nogales. The NAM is considered to represent the most important source of water for recharge. We selected the Hadley Centre Coupled Model Version 3 (HadCM3) as the best for simulating precipitation for the USA-Mexico border study area based on a personal communication with $\mathrm{M}$. Montero (Instituto Mexicano de Tecnología del Agua, February 23, 2009) who compared historical records with simulated precipitation for 1961 to 1990 . HadCM3 had the highest correlation coefficient (0.917) with the lowest root mean square deviation (0.550 $\mathrm{mm} \mathrm{d}^{-1}$ ) among all 15 general circulation models evaluated). Fig. 7 presents HadCM3 simulated precipitation during 2000-2099 over the study area, extracted for the grid cell $\left(32^{\circ} \mathrm{N}\right.$, 


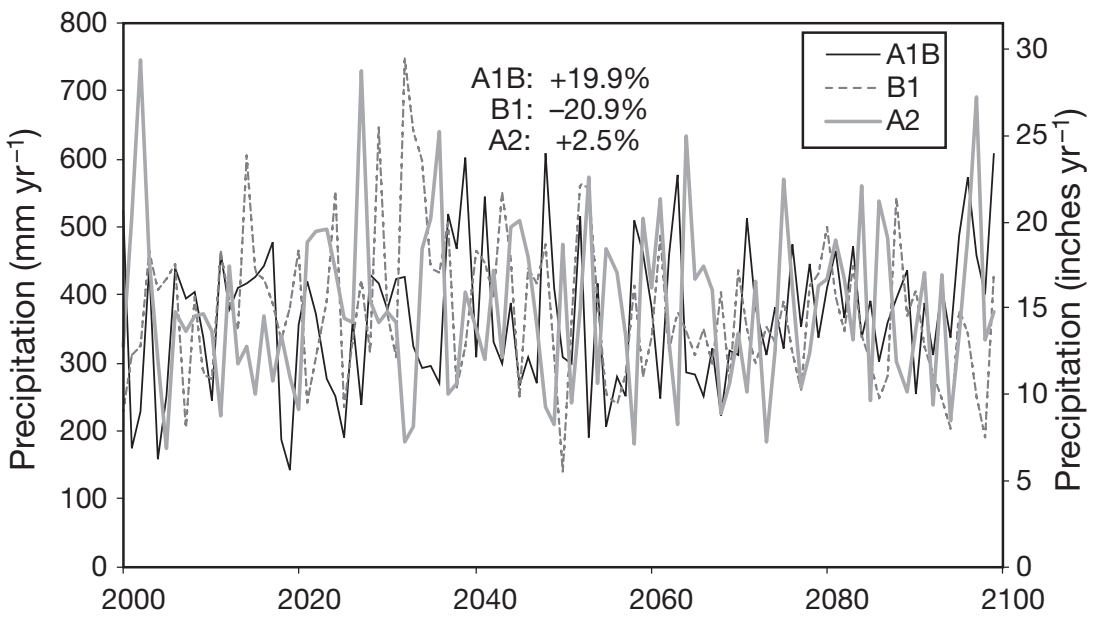

Fig. 7. Projected precipitation (using HadCM3) for $32^{\circ} \mathrm{N}, 110^{\circ} \mathrm{W}$, under different carbon emission scenarios. Percentage values in graph: change in annual precipitation over the 21st century (2000 to 2099) as percent of annual mean for the first decade (2000 to 2009) most pessimistic (highest carbon) A1FI levels (Raupach et al. 2007). Fig. 7 indicates that precipitation will change over the 21st century by -21 to $+20 \%$ depending on the emissions scenario. A1B precipitation is the least variable with an increasing trend over the century; B1 and A2 are highly variable, with B1 simulating a decreasing trend. All scenarios exhibited increasing temperatures (Scott 2011, Magaña et al. 2012), which combined with projected prolonged heat waves (Diffenbaugh et al. 2005), are expected to raise demand for groundwater while diminishing recharge. $\left.110^{\circ} \mathrm{W}\right)$ centered on the Santa Cruz aquifer as 2degree resolution data from the World Climate Research Programme's Coupled Model Intercomparison Project using Dominguez et al. (2010). The precipitation time-series covers the period of population projections for the Santa Cruz aquifer as detailed below.

Of the 3 Intergovernmental Panel on Climate Change (IPCC 2007) 4th Assessment Report (AR4) scenarios used, A1B is considered conservative with lower carbon emissions than A2 and less optimistic (more carbon) than B1. However, since the AR4 was published, actual emissions for recent years have exceeded levels for all these scenarios as well as the

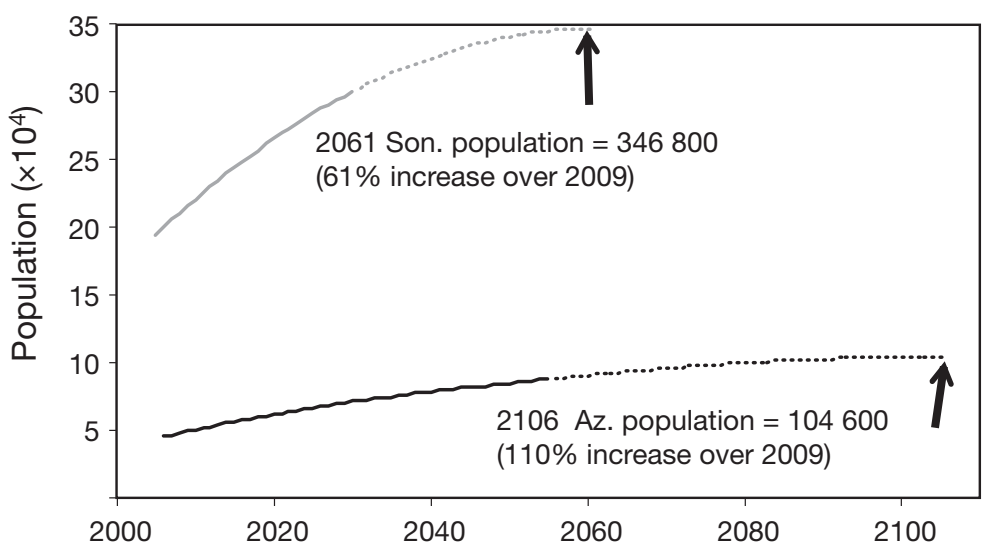

Fig. 8. Projected population growth in Sonora (Nogales and Santa Cruz municipal district) and Arizona (Nogales and Santa Cruz County) portions of the Santa Cruz aquifer. Solid line: projection; dotted: trend to stable population. Gray: Sonora; black: Arizona. Source-Arizona Department of Commerce (ADC 2006); Sonora: Instituto Nacional de Estadística, Geografía e Informática (INEGI 2005)

\subsection{Urban growth and increasing water demand}

Human withdrawals have important impacts on the water balances. Recent population data indicates that the border between the USA and Mexico is experiencing rapid economic and population growth, despite the 2008 to 2009 financial turmoil and real estate downturn (Norman et al. 2010). In this region of limited surface water supplies, the water demands of growing populations and increasing economic activity are met using groundwater.

Arizona is one of the fastest growing states in the USA, with population growth taking place mostly in towns and cities (Colby et al. 2007). In tandem with the growth trends on the USA side of the border, Mexican border states and cities continue to experience growth in population and economic activity that outpaces the national average. Border sister cities have populations that are significantly greater on the Mexican side than on the USA side (Varady \& Morehouse 2004), e.g. Fig. 8. In Santa Cruz County, Arizona, (where the Santa Cruz aquifer is located), the population is currently growing at $1.3 \% \mathrm{yr}^{-1}$ and is projected to continue growing into the next century (Arizona Department of Commerce [ADC] 2006). In the municipalities of Nogales and Santa Cruz, Sonora, the population is larger and is growing more rapidly at $1.6 \% \mathrm{yr}^{-1}$ (INEGI 2005) than in the Arizona por- 
tion; both municipalities rely on the Santa Cruz aquifer. The Sonora population is projected to stabilize by about 2060, earlier than in Arizona, as shown in Fig. 8. As the demographic models used for these projections differ, any multi-decadal projection is subject to considerable uncertainty.

For the Mexican side of the border, the municipio (roughly equivalent to a USA county) is the unit for population analysis. The Mexican projections take into account regional immigration and emigration from the municipio, as well as net international migration (Partida Bush 2008). The Arizona projection used the State of Arizona Composite Estimates Method. Age and sex are disaggregated at the county level, but international out-migration is not factored against in-migration (ADC 2007). For both sides of the border, data from each nation's 2000 census is used as baseline and compared to 2005 population estimates.

Rapid population growth that occurs primarily in urban centers has 2 principal implications for groundwater resources. First, 'human consumption' of water (consumo humano) has priority over other uses in Mexican federal legislation, and as a result installed pumping capacity for urban water supply is expected to continue to grow. Second, Nogales, Sonora, currently has a relatively low per capita water supply of 180 liters per capita per day (lpcd). This figure includes residents who receive piped water supply (Organismo Operador Municipal de Agua Potable, Alcantarillado y Saneamiento [OOMAPAS] \& Alliance to Save Energy [ASE] 2008). In addition, there is a large and growing population living in informal settlements (colonias marginales) without access to household-level water supply (Wilder et al. 2011), whose water consumption is less than half of $180 \mathrm{lpcd}$. Plans to extend supply to these under-served communities will undoubtedly continue to exert pressure on Santa Cruz aquifer resources. OOMAPAS is the municipal water utility in Nogales, Sonora. It uses 3 pumping areas to supply the urban population. The Mascareñas well field, which is located on the Santa Cruz River, currently produces $213 \mathrm{l} \mathrm{s}^{-1}$. The Nogales Wash, a tributary of the Santa Cruz River, is also used for municipal supply, and produces $169 \mathrm{l} \mathrm{s}^{-1}$. The Los Alisos Basin, located to the south of the city and part of the Rio Magdalena basin, supplies $339 \mathrm{l} \mathrm{s}^{-1}$ (OOMAPAS \& ASE 2008).

Nevertheless, for groundwater resources that are already under pressure (see previous section), these growth projections have serious implications. Per capita water use in Arizona is diminishing but is not expected to drop by a half to offset the approximate doubling of population before it stabilizes. In the absence of new sources of supply, this implies reallocation of water currently used in agriculture and reuse of effluent for human purposes (landscaping irrigation and/or, potentially, indirect potable use through recharge of effluent and ground-water pumping for potable supplies). The water supply situation in Sonora is more challenging given the larger increases in absolute population numbers and the fact that close to half the water demand is already being met through inter-basin transfer from Los Alisos basin to the south.

\subsection{Relative climate and human drivers of groundwater balance}

To illustrate the implications for the Santa Cruz aquifer of climate variability coupled with growing water demand, we undertook a sequential climate and human-demand forcing of the combined USAMexico aquifer balance, following Loaiciga (2003). Current recharge was held constant and the partial effect of urban water demand was examined by increasing this in proportion to population growth. Next, the partial effects of climate change scenarios (A1B, B1, and A2) were calculated by varying recharge with projected precipitation (see justification of this assumption below). Finally, the combined effects of population growth and precipitation-based recharge were calculated.

Our assumptions are as follows. The average ratio of annual recharge to precipitation over wet and dry years for which data were available (1998 to 2002; from Erwin 2007) was applied to the modeled 2000 to 2099 precipitation series, in order to estimate annual recharge series. Even when precipitation is highly seasonal, all other factors being constant, the resulting annualized natural recharge (water flowing across the water table from non-anthropogenic sources) approaches a constant percentage of annual precipitation. It is therefore appropriate to estimate natural recharge in this manner (Pool \& Dickinson 2006). Nelson (2007), and Flint \& Flint (2007) estimated recharge as a percentage of precipitation. Nelson (2007) used constant values for both mountain front and tributary recharge in the Santa Cruz, and Flint \& Flint (2007) used a recharge rate of $15 \%$ of mountain precipitation for their work on basins throughout the southwestern USA. Our analyses are intended to illustrate trends (Fig. 9) resulting from variability in aquifer balance recharge and withdrawal components. 


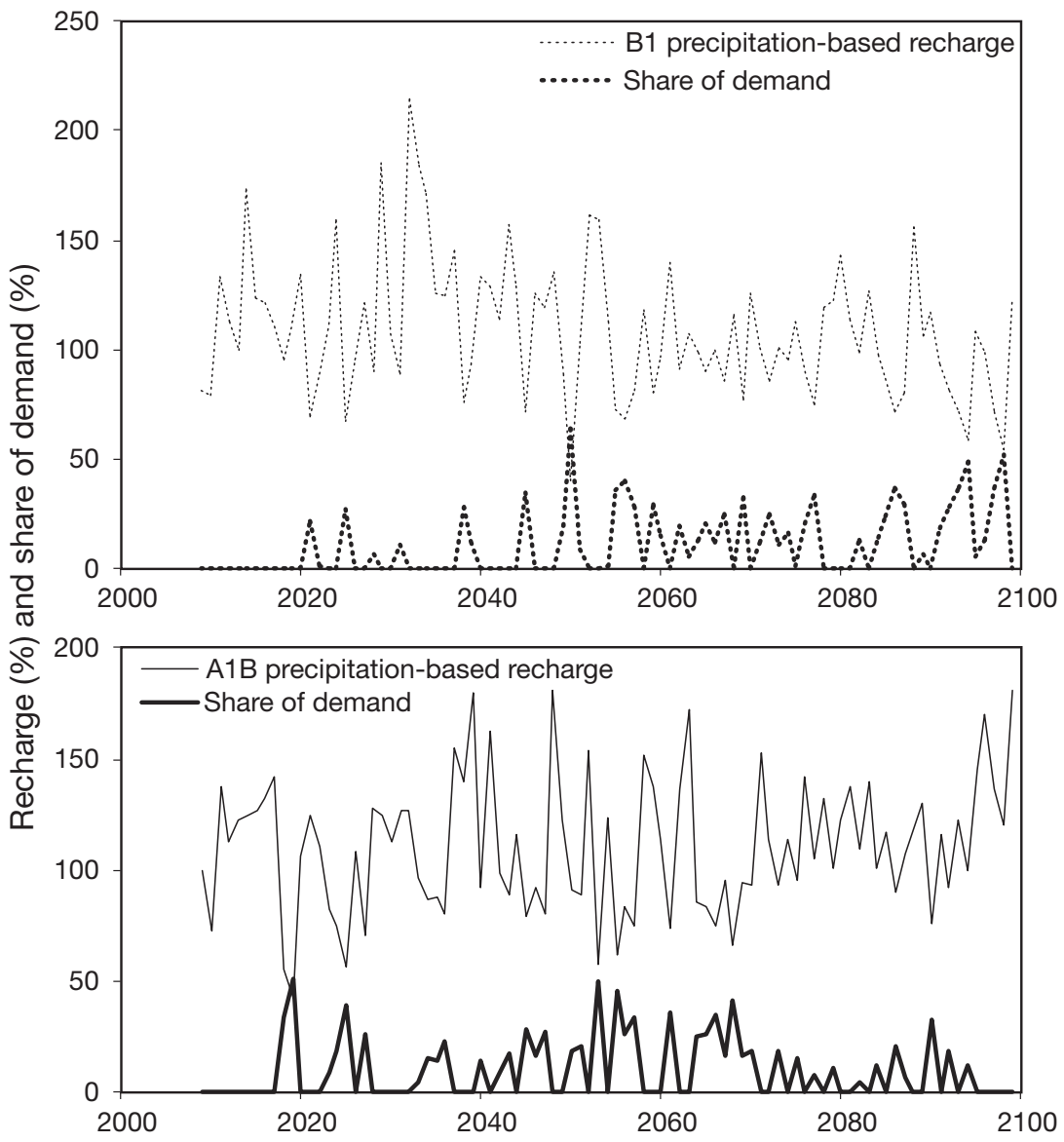

Fig. 9. Scenario assessment (using HadCM3) of growth in water demand and recharge under climate variability, Santa Cruz Aquifer, Sonora, Mexico. Precipitation-based recharge: $2000-2009$ mean $=100 \%$; share of demand: demand that must be met through non-aquifer sources or conservation

results with increasing precipitation trends indicate the highest recharge, while those for B1 indicate the lowest recharge. Although the results suggest that the aquifer will remain in positive balance under projected future conditions (and would thus likely contribute to surface baseflow), the relative USA and Mexico shares of the balance are not addressed.

For further analysis, we omit the A2 scenario, given that its precipitation projections to the year $2099(+2.5 \%$ compared to the 2000 to 2009 mean precipitation) are between those of B1 $(-20.9 \%)$ and A1B $(+19.9 \%)$, as seen in Fig. 7. Fig. 9 shows the results of the projected urban and industrial water supply sufficiency for Nogales, Sonora.

The implications of the scenario analysis displayed in Fig. 9 are 4 -fold. (1) Water service expansion in Sonora will require additional investment in infrastructure to meet the rising share of demand that will need to come from non-aquifer sources and conservation. After 2060, population is projected to stabilize in Nogales, Sonora, and the aquifer is expected to enter a phase of heightened demand management, conservation, and water reuse. While the simulation for the

\section{RESULTS AND DISCUSSION}

Table 2 shows the simulation results of the water balance components that are influenced by projected future changes, i.e. recharge varies with climate change and urban/industrial demand for water varies with population growth. As expected, the A1B
A1B scenario indicates that the period from 2060 through to the end of the century may be characterized by increased rainfall (and thus recharge), the simulation for the B1 scenario indicates that the second part of the century will result in greater unmet demand. (2) Water to supply growing urban demands will need to be accessed from agriculture, waste-

Table 2. Simulated sequential climate and human-demand forcing of Santa Cruz water balance, $2099\left(10^{6} \mathrm{~m}^{3} \mathrm{yr}^{-1}\right)$. ET: evapotranspiration

\begin{tabular}{|c|c|c|c|c|c|c|c|}
\hline \multirow[t]{2}{*}{ Component } & \multirow{2}{*}{$\begin{array}{l}\text { Population } \\
\text { growth }\end{array}$} & \multicolumn{3}{|c|}{$\begin{array}{l}\text { Partial effect } \\
\quad \text { Recharge }\end{array}$} & \multicolumn{3}{|c|}{$\begin{array}{c}\text { Combined population growth } \\
\text { \& recharge }\end{array}$} \\
\hline & & $\mathrm{A} 1 \mathrm{~B}$ & $\mathrm{~A} 2$ & B1 & A1B & A2 & B1 \\
\hline Recharge & 116.1 & 128.5 & 126.6 & 110.2 & 128.5 & 126.6 & 110.2 \\
\hline Urban/industrial withdrawals & 58.8 & 33.7 & 33.7 & 33.7 & 58.8 & 58.8 & 58.8 \\
\hline $\begin{array}{l}\text { Other withdrawals } \\
\text { (agriculture, riparian ET, outflow) }\end{array}$ & 48.6 & 48.6 & 48.6 & 48.6 & 48.6 & 48.6 & 48.6 \\
\hline Recharge - withdrawals & 8.7 & 46.2 & 44.3 & 27.9 & 21.1 & 19.2 & 2.8 \\
\hline Recharge/ withdrawal ratio & 1.1 & 1.6 & 1.5 & 1.3 & 1.2 & 1.2 & 1.0 \\
\hline
\end{tabular}


water, and out-of-basin sources, such as currently pumped from Los Alisos basin. We estimate that after 2060 half or more of total demand will need to be met from non-aquifer sources. (3) Climate change, as simulated by the HadCM3 A1B and B1 scenarios, drives significant variability in water availability. The generally shallow Mexican portion of the aquifer means that recharge variability translates into water supply variability on an annual basis. (4) In the absence of water importation and with agricultural water use and rights increasingly appropriated for urban demand, it is inevitable that wastewater will be seen as a resource to meet urban demand. This has major implications for binational negotiations over effluent treated and released on the USA side by the Nogales International Wastewater Treatment Plant (NIWTP, operated by the USA Section of the IBWC) and for the downstream riparian corridor in the USA that depends on effluent flows.

What is particularly relevant is the transboundary contrast in water balances and demand. Thus, we turn next to an ongoing set of binational assessment activities that seek to address these contrasts in the context of limited data on which to base management decision making.

\section{AQUIFER ASSESSMENT PROCESS}

The analyses reported in this paper were conducted as part of the USA-Mexico TAAP, with relevant background as follows. Growing demand for groundwater in the USA-Mexico border region has raised the profile of transboundary groundwater resources in the USA. As a result, the USA-Mexico Transboundary Aquifer Assessment Act ('the Act') gained approval of the 109th Congress of the USA and was signed into law by the President on December 22, 2006. The purpose of the TAAP is to provide state, national, and local officials with information to address pressing water resource challenges in the USA-Mexico border region. As finalized, the Act authorizes the Secretary of the Interior, through the USA Geological Survey (USGS), to collaborate with the states of Arizona, New Mexico and Texas, as well as Mexico and others, to conduct hydrologic characterization, mapping and assessments of priority transboundary aquifers. The TAAP has an appropriations ceiling of US\$50 million over $10 \mathrm{yr}$, although funds are appropriated annually and expected to be split equally among the states of Arizona, New Mexico, and Texas. California determined it would not participate. Each of the 3 participating state's funds are to be split equally between the USGS and that state's Water Resources Research Institute (WRRI), located at one of the state's universities as stipulated by the Water Resources Research Act. The WRRIs have active, ongoing partnerships with the USGS. This mechanism for TAAP implementation is a unique model of federal agency-university center partnership for program implementation.

For Arizona, the 2 priority transboundary aquifers established in the legislation are the Santa Cruz River Valley and San Pedro aquifers. An ongoing and intensive process of water resources management, coordinated by the Upper San Pedro Partnership in the USA, has generated scientific investigation and policy assessment for the San Pedro River and aquifer, even though the binational aquifer itself has not been the focus. As a result, for this paper, we determined that focusing on the Santa Cruz Aquifer would contribute to broader understanding.

The process of binational consultation and priority setting for the Santa Cruz aquifer began in 2007. Reflecting the TAAP's design of federal-state collaboration on the USA side, the Water Resources Research Center (WRRC, the state's designated water resources institute located at the University of Arizona) and USGS's Tucson office form the de facto TAAP-Arizona executive committee. A technical committee was identified, largely through selfselection of interested stakeholders, to review existing studies, both hydrogeological and institutional in nature, leading ultimately to the prioritization of aquifer assessment activities, research, and additional exchange of information among stakeholders. The timing and amount of TAAP financial resources also played a determining role in the pace that could be maintained, i.e. initial funding during fiscal years 2007 to 2008 and 2008 to 2009 were sufficient to cover a TAAP coordinator and modest support for field trips (one each on the USA and Mexican sides during mid-2008). Increased funding in 2009 to 2010 allowed additional work to be undertaken, under the provision that USA funds could be used for TAAP activities in Mexico on the condition that Mexico provided a $50 \%$ cost match in cash or kind. However, lack of USA federal budget support in 2010 to 2011 meant that activities are being continued using existing funding. Future funding will be critical to the outcome of the program.

As a result of the consultation and technical exchanges outlined here, the technical committee report includes the following, reflecting priorities on both sides of the border: 'The consultation process for the aquifer has identified water availability (implying 
concomitant water quality) to meet growing demands as the overarching goal. The implications of climate change and variability are also important concerns'. We summarize the priorities identified as: (1) water availability for urban areas particularly to meet peak summer demands, (2) linked surface and groundwater systems that are a primary mechanism of aquifer recharge, (3) water quality of aquifers used for potable supply, and (4) comparative assessment of institutions for the management of water resources.

Institutional asymmetries in governmental function (Milman \& Scott 2010, Megdal \& Scott 2011) require careful consideration when developing a binational plan of study. For example, under Mexican water law, the federal government is responsible for surface and groundwater rights (Mumme 2000, Scott et al. 2010), whereas individual states in the USA oversee groundwater use and much surface water use. By treaty, the IBWC (USA section) and CILA (Mexican section) serve as the binational coordination mechanism for surface water, including in some instances cross-border wastewater treatment. In the USA, however, the IBWC has very limited responsibility for groundwater and the TAAP authorizing legislation established the USGS as the lead federal agency.

In this context, the binational assessment process in the Arizona-Sonora region has identified priority technical and management studies that require additional investment. Currently, TAAP 2009 to 2010 funds are being used to generate new hydro-climatological and institutional data.

\section{CONCLUSIONS}

The HadCM3 model results assessed herein indicate that precipitation projections in the study area depend on the emissions scenario used, and may be expected to change by $-21 \%$ to $20 \%$ over the 21 st century. Precipitation projections for the A1B emissions scenario show increasing trends, while projections for the B1 and A2 scenarios are highly variable and the B1 projection indicates a decreasing precipitation trend. All projections exhibited increasing temperatures. These scenarios raise the specter of longer, more severe droughts (Magaña et al. 2012). Combined with the implications of increased tropical storms and intense precipitation (Karl et al. 2009), the likelihood of future flooding is significant.

The availability of groundwater in the USAMexico border region is compounded by growth in demand driven by increasing population and climate-induced variability in recharge. The Mexican portion of the Santa Cruz aquifer already supports much less agriculture and much more urban use than does the USA portion of the aquifer. As a result, there is little remaining agricultural water to transfer to urban use for Nogales, Sonora. If growth continues as projected, additional water will be required from outside the Santa Cruz aquifer and basin; this is already underway from the Alisos Basin to the south of Nogales, Sonora. The USA side has slower population growth, but is projected to continue expanding for a longer time. In the short- and medium-term, transferring water out of agriculture in the USA may offset growth-driven water demand. Also, on the USA side of the border, the Arizona Department of Water Resources (ADWR) has prioritized maintaining safe-yield conditions (where pumping equals estimated groundwater recharge) in the Santa Cruz Active Management Area (SCAMA). Currently, the City of Nogales in conjunction with the SCAMA and Santa Cruz Grandwater Users Advisory Committee is in consultation with the US Bureau of Reclamation to explore potential enhancement of the municipal water supply through augmentation using water sources.

Wastewater is a critical resource to support overall water demand; currently, it is largely generated in Mexico and meets riparian evaporative demand on the USA side. However, as the resource value of wastewater increases, Mexico may opt to capture, treat, and reuse wastewater to meet its own growing water demand. This is currently underway with the construction of the Los Alisos wastewater treatment plant that takes a share of the wastewater from Nogales, Sonora, back over the watershed divide into the Alisos basin where it will be treated and released. A significant share of the wastewater generated in Mexico will continue to flow to the USA, requiring ongoing technical and organizational collaboration. If Mexico opts to retain control over effluent currently treated at the NIWTP, the most significant repercussion may occur along the riparian area and associated cottonwood/willow gallery forest directly downstream from the treatment plant. There has not been extensive analysis of potential scenarios if this source of surface flow is reduced.

In the context of differing institutional arrangements for water management in the USA and Mexico, a binational consultation process to establish priority assessment activities for the shared Santa Cruz aquifer as part of the TAAP has demonstrated the value of technical exchanges, ongoing consultation, and consensus building through joint field visits. 
The role of binational institutions, in this case IBWC/CILA and the Arizona-Mexico Commission, is critical for the exchange of information; however, collaborative mechanisms initiated and pursued more locally, in this case between Arizona and Sonora, offer greater possibilities for sustained exchange of information. The successful example of the Santa Cruz priority-setting process by TAAP-Arizona is based on binational collaboration incorporating federal, state, and local agencies, universities, and civil society. The role played by university and agency researchers in devising collaborative mechanisms complements regulatory functions and civil society's advocacy positions.

Acknowledgements. The binational aquifer priority-setting process analyzed in this paper was supported by the USAMexico TAAP. The authors would like to acknowledge the active participation of the following agencies: ADWR, OOMAPAS (Nogales Sonora), Friends of the Santa Cruz River, CILA, IBWC, US Bureau of Reclamation, and City of Nogales, Arizona. Additional support for coordination was provided by the University of Arizona's Water Sustainability Program. Groundwater and population scenario analysis was supported by the National Science Foundation (Grant DEB1010495) and by the Inter-American Institute for Global Change Research (Project SGP-HD \#005, which is supported by National Science Foundation Grant GEO-0642841). Finally, the IPCC AR4 data were provided by SAHRA (Sustainability of semi-arid Hydrology and Riparian Areas) at the University of Arizona (F. Dominguez, J. Cañon and J. Valdes). The original dataset comes from the World Climate Research Programme's (WCRP's) Coupled Model Intercomparison Project phase 3 (CMIP3) multi-model dataset.

\section{LITERATURE CITED}

Arizona Department of Commerce (ADC) (2006) Research Administration, Population Statistics Unit. Available at: www.azcommerce.com/more-info.aspx?url=/econinfo/ demographics/Population\%20Estimates.html (Accessed February 24, 2009)

Arizona population statistics policies. Policy Number: 045Z 05-02-01. Arizona Department of Commerce. Phoenix, AZ. Available at: http://old.azcommerce.com/doclib/ econinfo/FILES/WFCompositeEstimatesMethodologyVer4. pdf

ADWR (Arizona Department of Water Resources) (2008) Arizona water atlas-draft, 2008. Available at: www.azwater. gov/AzDWR/StatewidePlanning/WaterAtlas/default.htm (Accessed April 15, 2008)

Brekke LD, Dettinger MD, Maurer EP, Anderson M (2008) Significance of model credibility in estimating climate projection distributions for regional hydroclimatological risk assessments. Clim Change 89:371-394

Castro-Escárrega JJ, Morales-Morales H, Salazar-Velásquez R (2000) Carta Geológico-Minera Nogales H12-2 Sonora. Servicio Geologico Mexicano

Cevera Gomez LE, Rodríguez Estevez JM (1997) Proyecto de investigación: relación población-ambiente en la cuenca del Río Santa Cruz: uso integrado de sistemas de información geográfica y percepción remota. El Colegio de la Frontera Norte, Nogales

Colby BG, Jacobs KL, Smith DR (2007) Lessons for semi-arid regions facing growth and competition for water. In: Colby BG, Jacobs KL (eds) Arizona water policy. RFF Press, Washington DC, p 219-234

Diffenbaugh NS, Pal JS, Trapp RJ, Giorgi F (2005) Finescale processes regulate the response of extreme events to global climate change. Proc Natl Acad Sci USA 102: 15774-15778

$>$ Diffenbaugh NS, Giorgi F, Pal JS (2008) Climate change hotspots in the United States. Geophys Res Lett 35: L16709 doi:10.1029/2008GL035075

> Dominguez F, Cañon J, Valdes J (2010) IPCC-AR4 climate simulations for the Southwestern US: the importance of future ENSO projections. Clim Change 99:499-514

Drewes H, Fields RA, Hirschberg GM, Bolm KS (2002) Spatial digital database for the tectonic map of Southeast Arizona. US Geological Survey Geol Invest Ser I-1109, Digital Database, version 2.0. Available at: http://pubs. usgs.gov/imap/i1109/ (Accessed March 3, 2010)

Earman S, Dettinger M (2011) Potential impacts of climate change on groundwater resources - a global review. J Water Clim Chang 02:213-229

Erwin G (2007) Ground water flow model of the Santa Cruz active management area microbasins: international boundary to Nogales international wastewater treatment plant, Santa Cruz County, Arizona. Modeling Rep No. 15, Arizona Department of Water Resources, Phoenix, Arizona

Flint LE, Flint AL (2007) Regional analysis of ground-water recharge. US Geological Survey Professional Paper 1703-B

INEGI (Instituto Nacional de Estadística Geografía e Informática) (2005) Población total de los municipios a mitad de año, 2005-2030. Available at: www.inegi.org.mx/ sistemas/olap/proyectos $/ \mathrm{bd} /$ consulta.asp? $\mathrm{p}=10215 \& \mathrm{c}=$ $16851 \& \mathrm{~s}=\mathrm{est} \#$

IPCC (2007) Climate change 2007: The physical science basis. Contribution of Working Group I to the Fourth Assessment Report of the Intergovernmental Panel on Climate Change. Cambridge University Press, Cambridge

Karl TR, Jerry M Melillo, Peterson TC (eds) (2009) Global climate change impacts in the United States. Cambridge University Press, Cambridge

> Lin JL, Mapes BE, Weickmann KM, Kiladis GN and others (2008) North American monsoon and convectively coupled equatorial waves simulated by IPCC AR4 coupled GCMs. J Clim 21:2919-2937

Loaiciga HA (2003) Climate change and ground water. Ann Assoc Am Geogr 93:30-41

Logan M (2002) The lessening stream: an environmental history of the Santa Cruz River. University of Arizona Press, Tucson, AZ

> Magaña V, Zermeño D, Neri C (2012) Climate change scenarios and potential impacts on water availiability in northern Mexico. Clim Res 51:171-184

Megdal SB, Scott CA (2011) The importance of institutional asymmetries to the development of binational aquifer assessment programs: the Arizona-Sonora experience. Water 3:949-963

Milman A, Scott CA (2010) Beneath the surface: intranational institutions and management of the United States-Mexico transboundary Santa Cruz aquifer. Environ Plann C Gov Policy 28:528-551

Mumme SP (2000) Minute 242 and beyond: challenges and 
opportunities for managing transboundary groundwater on the Mexico-US border. Nat Resour J 40:341-378

Nelson K (2007) Groundwater flow model of the Santa Cruz active management area along the effluent-dominated Santa Cruz River: Santa Cruz and Pima Counties, Arizona. Arizona Department of Water Resources Modeling Report no. 14. Available at: www.azwater.gov/ AzDWR/Hydrology/Modeling/documents/Modeling_ Report_14.pdf (Accessed March 3, 2010).

Norman LM, Huth H, Levick L, Shea Burns I, Guertin DP, Lara-Valencia F, Semmens D (2010) Flood hazard awareness and hydrologic modelling at Ambos Nogales, United States-Mexico border. J Flood Risk Manag 3:151-165

OOMAPAS \& ASE (2008) Proyecto de Eficiencia Física, Operación Hidráulica y Electromecánica, para la Ciudad de Nogales, Sonora. Informe Final, Agosto de 2008

Partida Bush V (2008) Proyecciones de la población de México de las entidades federativas, de los municipios y de las localidades (documento metodológico). Comisión Nacional de Población. México, D.F. Available at: www. conapo.gob.mx/00cifras/proyecta50/proyecciones.pdf (Accessed June 1, 2009)

Pool DR, Dickinson JE (2006) Ground-water flow model of the Sierra Vista subwatershed and Sonoran portions of the Upper San Pedro Basin, Southeastern Arizona, United States, and Northern Sonora, Mexico. US Geological Survey Sci Invest Rep 2006-5228

Raupach MR, Marland G, Ciais P, Le Quére C, Canadell JG, Klepper G, Field CB (2007) Global and regional drivers of accelerating $\mathrm{CO}_{2}$ emissions. Proc Natl Acad Sci USA

Editorial responsibility: Bryson Bates, Wembley, Australia
104:10288-10293

Richard SM, Reynolds SJ, Spencer JE, Pearthree PA comps. (2000) Geologic map of Arizona: Arizona Geological Survey Map M-35, 1 sheet, scale 1:1000 000. The Arizona Geological Survey, Tucson

Scott CA, Dall'erba S, Díaz-Caravantes R (2010) Groundwater rights in Mexican agriculture: spatial distribution and demographic determinants. Prof Geogr 62:1-15

Shamir E, Meko DM, Graham NE, Georgakakos KP (2007) Hydrologic model framework for water resources planning in the Santa Cruz River, Southern Arizona. J Am Water Resour Assoc 43:1155-1170

Tapia-Padilla G (2005) Aplicación de MODFLOW para la simulación hidrogeológica estacionaria de una porción de la cuenca del Río Santa Cruz, Sonora, México. MSc Thesis, Universidad de Sonora, Hermosillo

Towne DC, Stephenson LW (2003) Ambient groundwater quality of the San Rafael Basin: a 2002 baseline study. Arizona Department of Environmental Quality Open File Report 2003-01. Phoenix, AZ

Varady RG, Morehouse BJ (2004) Cuanto cuesta? Development and water in Ambos Nogales and the Upper San Pedro Basin. In: Kopinak K (ed) The social costs of industrial growth in Northern Mexico. Center for US-Mexican Studies, UCSD, La Jolla, CA

Wilder M, Slack J, Garfin GM, Scott CA and others (2011) Urban water vulnerability and institutional challenges in Ambos Nogales. Working Paper on Climate and Water Resources in the Arizona-Sonora Region. Udall Center for Studies in Public Policy, Tucson, AZ

Submitted: December 30, 2010; Accepted: September 30, 2011 Proofs received from author(s): February 10, 2012 